\title{
Educating and Empowering Entrepreneurs through Local Community Project in Malaysia - Financial Problems in SDSI Program
}

\author{
Azizan Asmuni, Hayrol Ag Shaffril, Jasmin Arif Shah, and Husnina Yusoff \\ Universiti Putra Malaysia, UPM, Serdang, Selangor, 43400, Malaysia \\ Corresponding e-mail: azizanas@upm.edu.my
}

\begin{abstract}
The One District One Industry program locally known as SDSI (Satu Daerah Satu Industri) initiated by the Malaysian government has begun to show the positive economic impact on rural entrepreneurs. In thriving for successful, the entrepreneurs faced a lot of obstacles and problems, particularly in finance problem. The main objective of this study is to examine the financial problems faced by the SDSI entrepreneurs. This research is a quantitative study which involving 206 entrepreneurs as respondents. SPSS was used and descriptive analyses such as cross tab, frequency, percentage, mean and standard deviation employed for describing the general data of the study. Results showed that cash flow and mortgage were the main financial problems faced by a majority of the respondents. To address these issues, it is recommended that government support for the entrepreneurs be further strengthened emphasizing on continuous training and education programs.
\end{abstract}

Keywords: empowering local community, entrepreneurship development, financial problems

\section{INTRODUCTION}

The One District One Industry program locally known as SDSI (Satu Daerah Satu Industri) initiated by the Malaysian government has begun to show positive economic impact on rural entrepreneurs. The Ministry of Finance of Malaysia has furthered intensified the SDSI by supporting entrepreneurs to start their own businesses through the entrepreneurship support programme (Kamarudin and Abd Wahid 2017). The increasing economic gap between rural-urban communities prompted the formulation of the One District One Industry Program or locally known as "Satu Daerah Satu Industri" (SDSI) in the Sixth Malaysia Plan (RMK6) in 1992. In the earlier of its existence, it was known as One Village One Product Programme or locally known as SKSI Program, an initiative adapted from the One Village One Programme (OVOP) in Oita Prefecture Japan. SKSP then was the responsibility of the Ministry of Agriculture, Ministry of Rural Development and Handicraft Development Cooperation. In 2002, the name SKSP was changed into One Village One Industry or locally known as SKSI and in 2003, it was renamed One District One Industry Program or locally known as SDSI, SDSI was regarded an essential step to enhance rural economic development as similar programs, such as the OVOP Programme (Japan), One Tambon One Product (OTOP) programme (Thailand) and OTOP programme (Philippines) have proven to be successful. This supports Mackenzie's (1992) notion that one of the key areas to boost rural economic development is through entrepreneurship.

The concept of SDSI refers to the development of one or two local products with the purpose of increasing income of the local community. Based on this concept, there are three main objectives of SDSI which are 1) to create chances for increasing income of local community 2) to provide the local community with advanced and developed socioeconomic activities and 3) to create individual district identity through one or two products and or services that have economic values and competitiveedge at the national and international level. The products of SDSI are mainly focused on food 
necessities, manufacturing, handicraft and traditional art, tourism and business services, agricultural product and other activities (such as massage, transportation services and daily services) (Igusa, 2009). In 2004, more than $50 \%$ of the districts in Malaysia came under the SDSI programme generating products such as crafts, food products, rural industry products, as well as services (Ministry of Entrepreneur and Cooperative Development, (MECD) 2004).

The determinants of a business success are diverse in nature. One of the most important factors is finance. (Rogof et al., 2004). The entrepreneurs need sufficient working capital. Walker and Brown (2004) agreed with this statement as they revealed that financial criteria are usually considered to be the most appropriate indicator for business success. The SME corps which is a government-linked company (GLC) was established to provide loans to entrepreneurs who want to run small and medium businesses. A stable cash flow is important as it allows entrepreneurs to provide goods and services to their customers, pay bills, and make improvements and possible expansions. Bank loan is another common financial problem faced by entrepreneurs as it involves a lot of bureaucratic procedures. Entrepreneurs need to be educated regarding factors that may potentially influence profit and loan repayments, as these factors are crucial for the success of their enterprises (Mmbengwa et al., 2011). Limited financial capability was revealed as the main problem faced by entrepreneurs. Other financial issues important for business success are capital requirements, mortgage, bookkeeping, financial planning, financial control, management of working capital and income generation (Brink et al., 2003).

\section{METHOD}

This is a quantitative study where a total of 206 entrepreneurs involved in the SDSI program were selected as respondents through random sampling. The survey was divided into five zones- the northern, central, east coast, southern and Sabah/Sarawak zone. A structured questionnaire was used involving trained enumerators to conduct the survey. Four main financial issues - cash flow, bank loan, mortgage and book keeping were included in the questionnaire. SPSS was used to run the analyses. Descriptive analyses such as cross tab, frequency, percentage, mean and standard deviations were done.

\section{RESULTS}

This study shows that there was a balanced distribution of male and female entrepreneurs. A total of 103 male entrepreneurs $(50.0 \%)$ and 103 female entrepreneurs $(50.0 \%)$ were interviewed. $32.1 \%$ of the entrepreneurs were in the age group of $30-40$ years old, and likewise for the group age of 41-50 years old. Only $12.5 \%$ were below 30 years old. More than half were secondary school leavers while $6.8 \%$ attended only primary school. $17.4 \%$ were university graduates. Nearly one third (31.4\%) were from the southern zone, $20.6 \%$ from the east coast zone, $18.6 \%$ from the central zone, $15.7 \%$, the southern zone and $13.7 \%$, Sabah/Sarawak zone. Majority of the entrepreneurs run their business on their own (61.6\%) while another $18.2 \%$ have business partners. More than two fifths employed less than 5 workers while only $2.5 \%$ had more than 100 workers. $9.1 \%$ of the entrepreneurs earned annual income of more than 1 million, depicting that SDSI programs have a huge potential to enhance economies of rural areas. Thus SDSI could be an effective mechanism to realize the objective of the New Economic Model (NEM), that is, to spearhead economic development of the country. Some $32.5 \%$ of the entrepreneurs have been involved in the SDSI program between $1-3$ years and another $25.1 \%$, for more than 9 years.

Seven demographic factors were crossed tab with four financial elements - cash flow, bank loan, mortgage and book keeping. Majority of the entrepreneurs were found to be facing cash flow problem, followed by mortgage-related problem. Entrepreneurs from all the zones except the east coast zones reported cash flow as their main problem while respondents from the east coast zone mentioned mortgage as their main problem. Apparently, book keeping was not a major financial problem, implying that the entrepreneurs had sufficient knowledge and skills in book keeping.

Five types of companies were studied - selfowned, partnership, private limited, cooperative and other types of business. The problem of cash flow and mortgage were frequently reported by the majority of self-owned company entrepreneurs. The problem regarding bank loan was faced by private limited and partnership. We can conclude that not many respondents were having problems of book keeping and bank loan. Only three respondents (1 self-owned, 1 private limited and 1 partnership) were detected to be having problem keeping their financial records while the same number was also 
recorded for bank loan problem (1 partnership and 2 private limited companies).

This study also showed that as the number of workers increase, lesser problems were encountered. Majority of the entrepreneurs who employed less than 5 workers indicated problems of cash flow and mortgage. Entrepreneurs who had more than 100 workers, did not have any problem regarding cash flow and bank loan, except for a few who had mortgage and book keeping problem. Majority from the group of 6 to 10 workers, 11 to 20 and 21 to 50 workers were reported to have cash flow problem. Some of the respondents in the group of 11 to 20 workers also had mortgage problem.

To analyse the relationship between average annual earnings and financial problems, the entrepreneurs were grouped into seven groups earning <10k, 11-50k, 51-100k, 101-200k, 201$500 \mathrm{k}, 500 \mathrm{k}-1$ million and $>1$ million. Majority of the entrepreneurs in the $51 \mathrm{k}-100 \mathrm{k}$ income group mentioned cash flow as their main problem, followed by the $11 \mathrm{k}-50 \mathrm{k}$ and $101 \mathrm{k}-200 \mathrm{k}$ income group. Mortgage problem is associated with the group of 11-50k followed by 51-100k.

This study pointed out that the more experienced entrepreneurs ( $>9$ years) faced all of the problems stated. They were facing problems of cash flow (15 entrepreneurs), bank loan (1 entrepreneur), mortgage (6 entrepreneurs) and book keeping (2 entrepreneurs). For the mortgage problem, 10 entrepreneurs in the group of 1 to 3 years, 6 entrepreneurs from the group of $>9$ years, 5 entrepreneurs from the group of 4 to 6 years, 4 entrepreneurs from the group of 7 to 9 years and 2 entrepreneurs from the group of $<1$ year were detected to be facing this problem.

Regardless of gender cash flow and mortgage are the two main problems reported. 30 female respondents and 29 male respondents informed that cash flow was their main financial problem. 13 male respondents and 15 female respondents were facing mortgage problem

The respondents were categorised into four age groups - $<30$ years old, 30-40 years old, 41-50 years old and $>50$ years old. Majority between the age group 30 to 40 and 41 to 50 were the main groups reported to have cash flow problem. Mortgage was the main problem faced by the group of $>50$ years old. 3 entrepreneurs in the group of 30 to 40 years also indicated that bank loan was their main problem. Bank problem was mainly faced by the age group of 30-40 years
The entrepreneurs were grouped into four education levels - primary school (standard 1 to standard 6), secondary school (<PMR/SRP, SPM/SPMV/MCE and STPM), Diploma and Degree or higher (including Master Science and PhD). The problems of cash flow and mortgage were mainly faced by entrepreneurs from the secondary school level of education. The problem of cash flow was a problem common to groups from the primary school level of education, diploma and degree or higher.

\section{DISCUSSION}

The SME sector has a vital role in the Malaysian economy to boost economic growth and create employment opportunities. The two main financial problems faced by the entrepreneurs studied were cash flow and mortgage. Addressing these problems is important as it can be the main determinant of their business success (Rogof et al., 2004 and Walker and Brown, 2004). There are some initiatives that can be taken to overcome these two main problems. First and foremost is government support (Kader et al., 2009).A good example is the initiative taken by SME Corps in conducting the SME Innovation Showcase 2011 and this should be followed up by related agencies. In 2010, the same event generated sales of RM93.32 million and events such as this will provide opportunity to SDSI entrepreneurs to promote and expand their business locally and abroad, thereby ensuring a more stable cash flow Similar events have been conducted in other countries such as Japan and Thailand which have proven to be successful. Furthermore, training programmes in business management, managerial skills and entrepreneurship should be endeavoured to address the issues of finance. Managerial skills for example are essential in organizing the physical and financial resources needed to run a business (Van Scheers and Radipere, 2007). Nonetheless, emphasis should be given to provide continuous and effective education and training to the lesser privileged entrepreneurs in programmes that will aid them in their business.

Among the 206 respondents to the questionnaire, several offered multiple responses to the question regarding business field - thus the total number of firms by business field is 251 . The field involving the largest number of firms -98 or just over $40 \%$ of the total - is food \& beverage. There are 40 firms (17\%) operating in the herb \& agricultural sector, making for a combined total of $60 \%$ in agriculture and food-related fields. (Many of 
the 90 firms with food-related operations also responded that they were manufacturing agriculturerelated products - almost all are engaged in the processing of agricultural goods.) Handcrafts are also an important field, making up $17 \%$ of the total with 45 respondents. Wood \& furniture accounts for $8 \%$ and textiles $6 \%$. Others even when machine \& tool and service fields are included, only constitute a small minority. Note: Firms engaged in two or more business fields were counted multiple times.

\section{CONCLUSION}

In terms of demographic data, majority of the respondents were in the age group of 30-40 years old and 41-50 years old, secondary school leavers, and came from the southern zone, They run their business themselves, employed 6-10 workers, and generate an average annual sales of $11-50 \mathrm{k}$. They have been involved in the SDSI program for 1-3 years. Among the four financial elements studied, cash flow and mortgage were the main problems faced. Bank loan and book keeping were not a major problem. Improved government support is suggested while effective and continuous education and training and seminars for entrepreneurial development is recommended.

The breakdown of firms by field of business provides a useful overview of SDSI-related enterprise in Malaysia as a whole. Many small-scale businesses in Malaysia are likely to be engaged in service industries including retail; the above findings, however, suggest that businesses targeted by SDSI are engaged chiefly in fields already well established in rural communities, such as agricultural goods and handcrafts. Together with the data presented earlier, this underlines SDSI's status as a program oriented primarily to support rural community.

\section{REFERENCES}

Brink A., Cant M, Ligthelm A (2003). Problems Experienced by small businesses in South Africa. Paper presented at 16th Annual Conference of Small Enterprise Association of Australia and New Zealand, 28 September - 1 October 2003, Ballarat Australia.

Igusa K (2009). SDSI policy in Malaysia. Paper presented at IOPA (International OVOP Policy Association) $3^{\text {rd }}$ Annual Conference, 15
November 2009. Nusa Dua, Denpasar Bali, Indonesia.

Igusa K. (2012). The OVOP Movement and Rural Entrepreneurs in Southeast Asia. Ritsumeikan Asia Pacific University.

Kader AR, Mohd Rosli M, Abdul Azid CI (2009). Success factors for small rural entrepreneurs under the One- District- One-Industry Programme in Malaysia. J. Contemporary Management Research, 5 (2): 147-162

Kamarudin, K. H. and Abd Wahid, S. N. A.b. (2017).One District One Industry Movement for Inclusive Rural Development and Beyond: the Case of Labu Sayong Entrepreneurs in Malaysia. Conference: 8th International Rural Research and Planning Group (RRPG) 2017, At Gadjah Mada University, Yogyakarta.

MacKenzie LR (1992). Fostering entrepreneurship as a rural economic development strategy.J. Economic Development Review, 10(4), 38-44.

MECD. (16 September 2004). One District One Industry.Unpublished report.

Mmbengwa VM, Ramukumba T, Groenewald, JA, VanSchalkwyk JD, Gundidza MB, Maiwashe AN (2011). Factors that influence the success and failure of land bank supported farming small, micro and medium enterprises (SMMES) in South Africa. J. Development and Agriculture Economics, 3 (2): 35-47

Rogoff EG, Lee MS, Suh DC (2004).Who done it? Attributions by entrepreneurs and experts of the factors that cause and impede small business success.J. Small Business Management, 42(4), 364-376.

Walker E, Brown A (2004). What success factors are important to small business owners? International Small Business J. 22 (6 ): 577594.

Van Scheers L, RadipereS(2007). Why are so many managers not “managing?".Afr. J. Business Management, July 2007: 85-91. 